\title{
Synergism of Mud Cake Modifier with Forming Agent of Agglomerated Cake at Cement-Formation Interface with MTA Method
}

\author{
Jun Gu*, Bo Wang, Jibiao He, Qinggui Wang, Guiping Wen, Pengfei Lai and Wenjie Du
}

Petroleum Engineering Department, Faculty of Earth Resources, China University of Geosciences, Wuhan 430074, China

\begin{abstract}
Based on the method of mud cake to agglomerated cake (MTA), the synergism of mud cake modifier (MCM) with forming agent of agglomerated cake (FAAC) in oil and gas well is studied by means of X-ray diffraction (XRD), environmental scanning electron microscopy (ESEM) and atomic absorption spectroscopy (AAS). The results show that the mud cake with MCM at cement-formation interface (CFI) is corroded by FAAC. And the corrosion spots and cracks are formed. The glassy substance in mud cake is depolymerized by hydrated ions from oilwell cement slurry through these spots and cracks. The soluble ionic groups in mud cake form. The diagenesis in mud cake at CFI occurs. The calcium silicate hydrates $(\mathrm{CSH})$, ettringite, film zeolite, rod zeolite and natrolite gels in mud cake generate. Ultimately, it achieves the integrated solidification and cementation (ISC) among cement paste, agglomerated cake and formation at CFI. This paper explains why the isolation quality of CFI is improved by the MTA method.
\end{abstract}

Keywords: Mud cake modifier, Forming agent of agglomerated cake, Ion, Diagenesis, Synergism.

\section{INTRODUCTION}

The isolation failure of cement-formation interface (CFI) is a main problem in well cementing of oil and gas wells [1], because the integrated solidification and cementation (ISC) among cement, mud cake and formation at CFI cannot be achieved [2]. Based on this, a method of mud to cement (MTC) emerged in the early 1990s [15]. By combining the MTC method and multifunctional drilling fluids, ISC was achieved. However, this method had been questioned by many scholars [3, 4]. They argued that the MTC solidified body was liable to the serious embrittlement. Thus the MTC method can only be used in the well cementing of surface casing and intermediate casing in oil and gas wells, as the MTC solidified body does not have the solidified performance of traditional oilwell cement [5].

Based on this, the new method of mud cake to agglomerated cake (MTA) to improve the isolation quality of CFI was proposed [6]. This method can be divided into two steps. Firstly, the mud cake modifier (MCM) is added into the drilling fluid before drilling to $50-200 \mathrm{~m}$ above the cementing interval. The MCM addition is from $0.5 \mathrm{wt} \%$ to 5.0 wt.\%. Secondly, the spacer fluid $\left(3-4 \mathrm{~m}^{3}\right)$ is prepared with forming agent of agglomerated cake (FAAC) [7]. Then this fluid and cement slurry is injected into the well in turn. In this new method, the cement slurry system is not changed. The evidences of ISC at CFI with MTA method were obtained $[8,9]$. The kinetic models of ISC with MTA

\footnotetext{
*Address correspondence to this author at the Petroleum Engineering Department, Faculty of Earth Resources, China University of Geosciences; No. 388, Lumo Road, Wuhan, 430074, China; Tel: +86-27-6784-8569; Fax:+86-27-6788-3051; E-mail: gujun2199@126.com
}

1874-1231/13 method were established [10]. The application effects of five oilfields in China showed the MTA method improves significantly the qualified rate and high quality rate of well cementing $[11,12]$. Based on X-ray diffraction (XRD), environmental scanning electron microscopy (ESEM) and atomic absorption spectroscopy (AAS), the synergism of MCM with FAAC was studied.

\section{EXPERIMENTAL}

\subsection{Experimental Material}

MCM (solid powder) and FAAC (liquid) are made inhouse. The chemical composition of MCM is listed in Table 1. The particle size distribution of MCM is shown in Fig. (1). The MCM addition is $5.0 \mathrm{wt} . \%$. The spacer fluid is composed of $85 \%$ tap water and $15 \%$ FAAC. The drilling

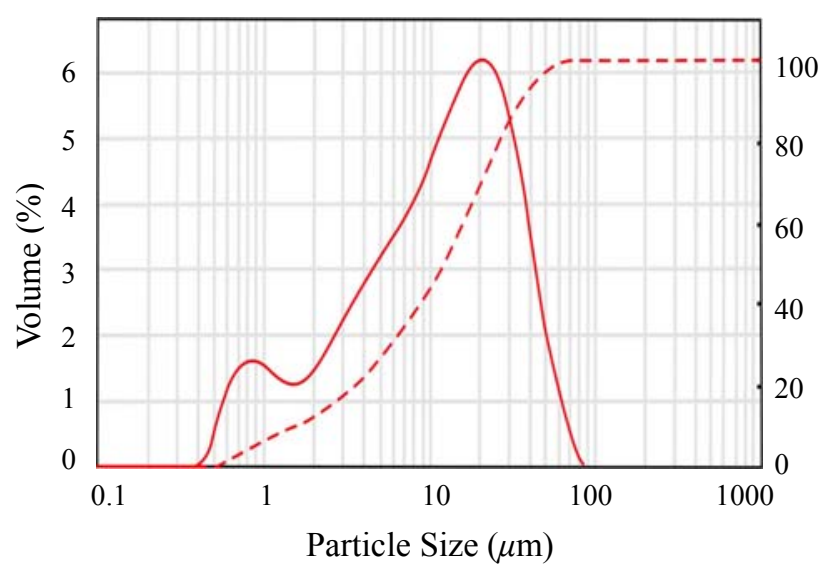

Fig. (1). Distribution of MCM particle size. 
fluid is from Henan oilfield in China. The formula of the cement slurry is Class G cement with $0.4 \%$ dispersant (USZ, from Henan oilfield) and $46 \%$ tap water.

\subsection{Sample Preparation of Corrosion Experiment}

The preparation condition is $0.69 \mathrm{MPa}$ for $30 \mathrm{~min}$ at room temperature. The thickness of mud cake samples is always $0.5 \mathrm{~mm}$.

The samples for corrosion experiment are prepared as follows:

- Make the drilling fluid into mud cake samples with ZNS water loss determinator (Qingdao Hisense optical communication Co., Ltd. in China). Then cut it into two same-size pieces, and labeled as samples A and B, respectively.

- Pour the drilling fluid into the pulp cup of JB-12K twoaxis high-speed agitator (Qingdao Hisense optical communication Co., Ltd. in China), and stir it for $20 \mathrm{~min}$ at 3 , $000 \mathrm{rpm}$. Then add $5.0 \mathrm{wt} . \%$ of MCM into the drilling fluid slowly, and stir them for $20 \mathrm{~min}$ at $12,000 \mathrm{rpm}$. Make the drilling fluid with MCM into mud cake samples by the same method, and labeled as sample $\mathrm{C}$.

- Soak sample A with tap water for 3 min, and soak samples $B$ and $C$ with FAAC at the same time. Then take out samples $\mathrm{A}, \mathrm{B}$ and $\mathrm{C}$, and put them into the drying apparatus. Get the dried samples.

\subsection{Sample Preparation of Diffusion and Resultant Ex- periment}

The curing time of experimental samples is 2 days. The curing temperature is $75^{\circ} \mathrm{C}$ in water. The curing pressure is $0.1 \mathrm{MPa}$. The mud cake thickness is $0.5 \mathrm{~mm}$. The permeability and porosity of simulated wellbores (SWB) are $450 \times 10^{-3} \mu \mathrm{m}^{2}$ and $26 \%$, respectively, which simulate the main isolation section in Henan oilfield. The outside diameter and inside diameter of SWB are $10.0 \mathrm{~cm}$ and 3.3 $\mathrm{cm}$, respectively. The height of SWB is $5.5 \mathrm{~cm}$. The preparation of SWB, formation of simulated mud cake, injection of oilwell cement slurry, curing of experimental samples can refer to the reference [13].

\subsubsection{Sampling Method of Diffusion Experiment}

The sampling method for AAS test of diffusion experiment is as follows:

- Prepare two kinds of samples. One is from inner layers of mud cake (e.g. near the cement paste), and its amount is $1.8567 \mathrm{~g}$. The other is from outer layers (e.g. near the formation), and its amount is $5.0119 \mathrm{~g}$.

- Put them into the digestion vessels, respectively. Then add the hydrochloride and nitric acid into the vessels. Proceed with digestion over the electric stove until the nitrogen oxide fumes are no longer given off. Then filter the solution, and clean the residues.

- Make up the final solution to $250.00 \mathrm{ml}$ with the distilled deionized water.

- Measure the concentrations of $\mathrm{K}^{+}, \mathrm{Na}^{+}, \mathrm{Ca}^{2+}, \mathrm{Mg}^{2+}$, $\mathrm{Fe}^{2+}, \mathrm{Zn}^{2+}$ and $\mathrm{Al}^{3+}$ by AAS.

\subsubsection{Sampling Method of Resultant Analysis}

The sampling method for XRD test of resultant analysis is as follows:

- Open the cured SWB.

- Scrape off the mud cake and agglomerated cake near the cement paste, respectively.

Table 1. Chemical Composition of MCM

\begin{tabular}{|c|c|c|c|c|c|c|}
\hline Chemical Composition & $\mathrm{SiO}_{2}$ & $\mathbf{C a O}$ & $\mathbf{F e}_{2} \mathbf{O}_{3}$ & $\mathbf{A l}_{2} \mathbf{O}_{3}$ & $\mathbf{M g O}$ & $\mathbf{L O I}$ \\
\hline \hline Percentage (\%) & 32.79 & 36.69 & 0.84 & 5.78 & 9.29 & 0.82 \\
\hline
\end{tabular}
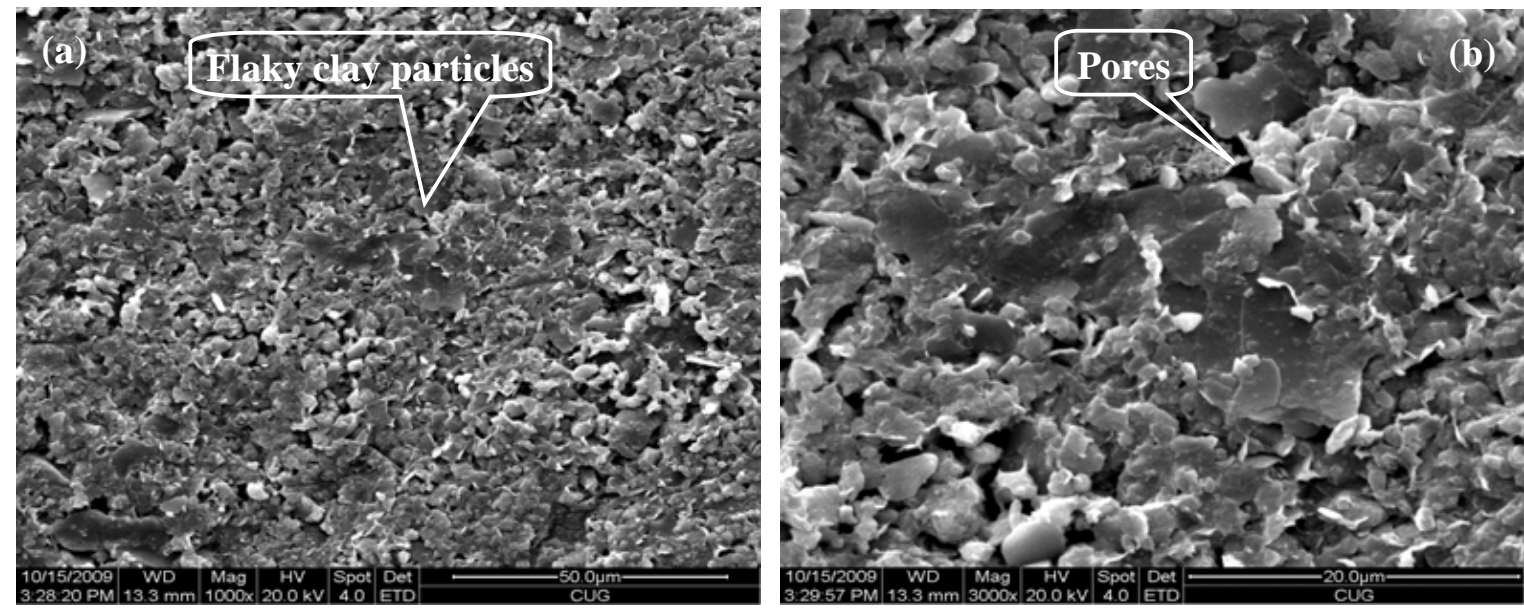

Fig. (2). ESEM micrographs of sample A: (a) $50 \mu \mathrm{m}$; (b) $20 \mu \mathrm{m}$. 
- Grind them into powder.

\section{RESULTS AND ANALYSIS}

\subsection{Corrosion of FAAC to Mud Cake}

The results of ESEM analysis carried out on samples A, $\mathrm{B}$ and $\mathrm{C}$ with different magnification are shown in Figs. (2), (3) and (4), respectively.

Fig. (2) shows that the structure of sample A is very loose and porous, and the cementation among the flaky clay particles in mud cake is poor. It could imply to obtain poor quality of well cementing, and lead to the isolation failure of CFI.

Fig. (3) shows that the surface of sample B is relatively smooth. But compared with sample A, the cementation among the flaky clay particles in mud cake is tighter. Besides, some gels and pores among the clay particles are formed. It is proved that the modification of FAAC on mud cake is obvious.

Fig. (4) shows that the corrosion spots and cracks are observed clearly. They distribute on the surface of mud cake and provide the channel for the diffusion of hydrated anion $\left(\mathrm{OH}^{-}\right)$and alkali metal cations $\left(\mathrm{Ca}^{2+}, \mathrm{K}^{+}, \mathrm{Mg}^{2+}, \mathrm{Fe}^{2+}\right.$, etc), into mud cake. Therefore, many gels are formed in the mud cake (e.g. MTA). Finally, the purpose of ISC at CFI could be achieved.

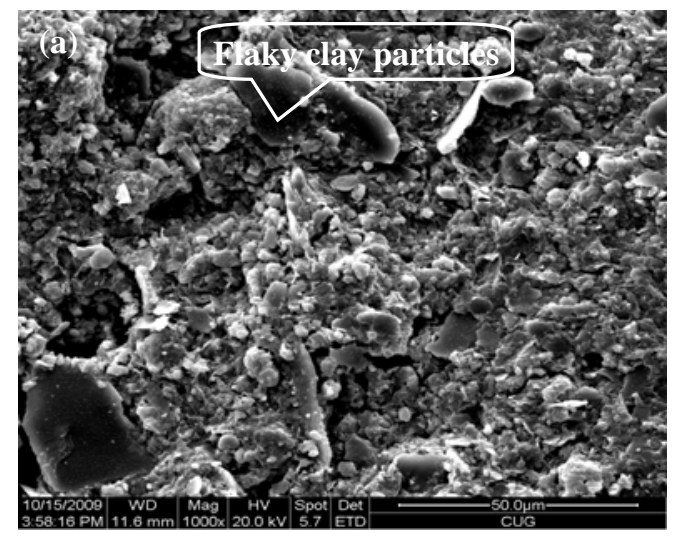

\subsection{Diffusion of Hydrated Ions from Cement Slurry}

The test results of alkali metal cation concentrations in inner and outer layers of agglomerated cake are listed in Table 2.

Table 2 shows that the cation concentrations in inner layer of agglomerated cake are higher than those in the outer layer. The concentration difference provides power for the diffusion of hydrated ions from the cement slurry into mud cake.

\subsection{Reaction Products of MCM with FAAC}

The XRD spectrums of mud cake and agglomerated cake samples are shown in Fig. (5).

Fig. (5a) shows that the mud cake sample is mainly composed of quartz, calcite, illite, feldspar and montmorillonite. Fig. (5b) shows that the gel materials have formed at CFI, such as calcium silicate hydrates ( $\mathrm{CSH})$, ettringite, film zeolite, rod zeolite and natrolite. ISC at CFI is achieved by these gels.

\section{SYNERGISM}

\subsection{Modification}

FAAC is made of $\mathrm{NaOH}, \mathrm{Na}_{2} \mathrm{SiO}_{3}, \mathrm{Na}_{2} \mathrm{SO}_{4}$, and $\mathrm{H}_{2} \mathrm{O}$, etc. The solution contains a lot of $\mathrm{OH}^{-}$. It reacts with clay minerals in mud cake, and leads to corrosion of silicon and replacement of aluminum. Consequently, the interface be-

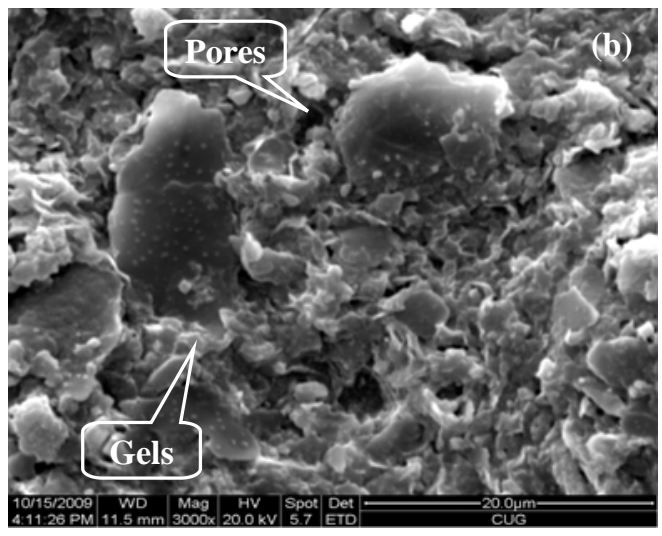

Fig. (3). ESEM micrographs of sample B: (a) $50 \mu \mathrm{m}$; (b) $20 \mu \mathrm{m}$.
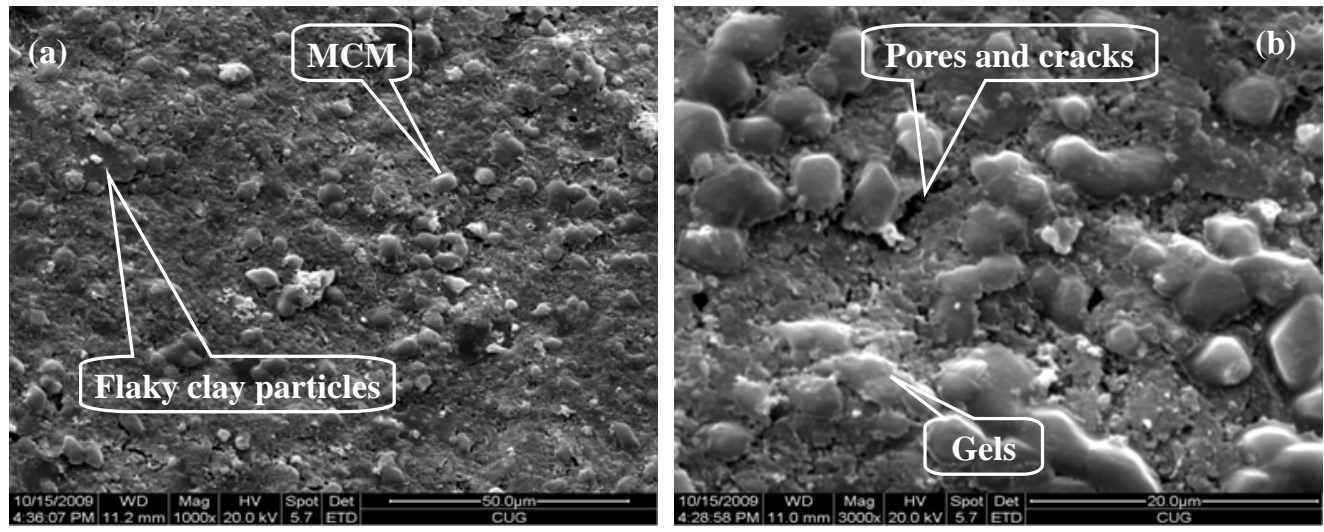

Fig. (4). ESEM micrographs of sample C: (a) $50 \mu \mathrm{m}$; (b) $20 \mu \mathrm{m}$. 
Table 2. Cation Concentrations in Inner and Outer Layer of Agglomerated Cake

\begin{tabular}{|c|c|c|}
\hline Ion Species & $\begin{array}{c}\text { Cation Concentrations in Inner Layer of Agglomerated } \\
\left.\text { Cake (mg } \mathbf{~ g}^{-1}\right)\end{array}$ & $\begin{array}{c}\text { Cation Concentrations in Outer Layer of Agglomerated } \\
\left.\text { Cake (mg. } \mathbf{g}^{-1}\right)\end{array}$ \\
\hline \hline $\mathrm{K}^{+}$ & 10.749 & 9.492 \\
\hline $\mathrm{Na}^{+}$ & 4.682 & 3.546 \\
\hline $\mathrm{Ca}^{2+}$ & 84.948 & 70.338 \\
\hline $\mathrm{Mg}^{2+}$ & 21.338 & 19.165 \\
\hline $\mathrm{Fe}^{2+}$ & 7.323 & 7.263 \\
\hline $\mathrm{Zn}^{2+}$ & 0.061 & 0.043 \\
\hline $\mathrm{Al}^{3+}$ & 1.274 & 1.046 \\
\hline
\end{tabular}

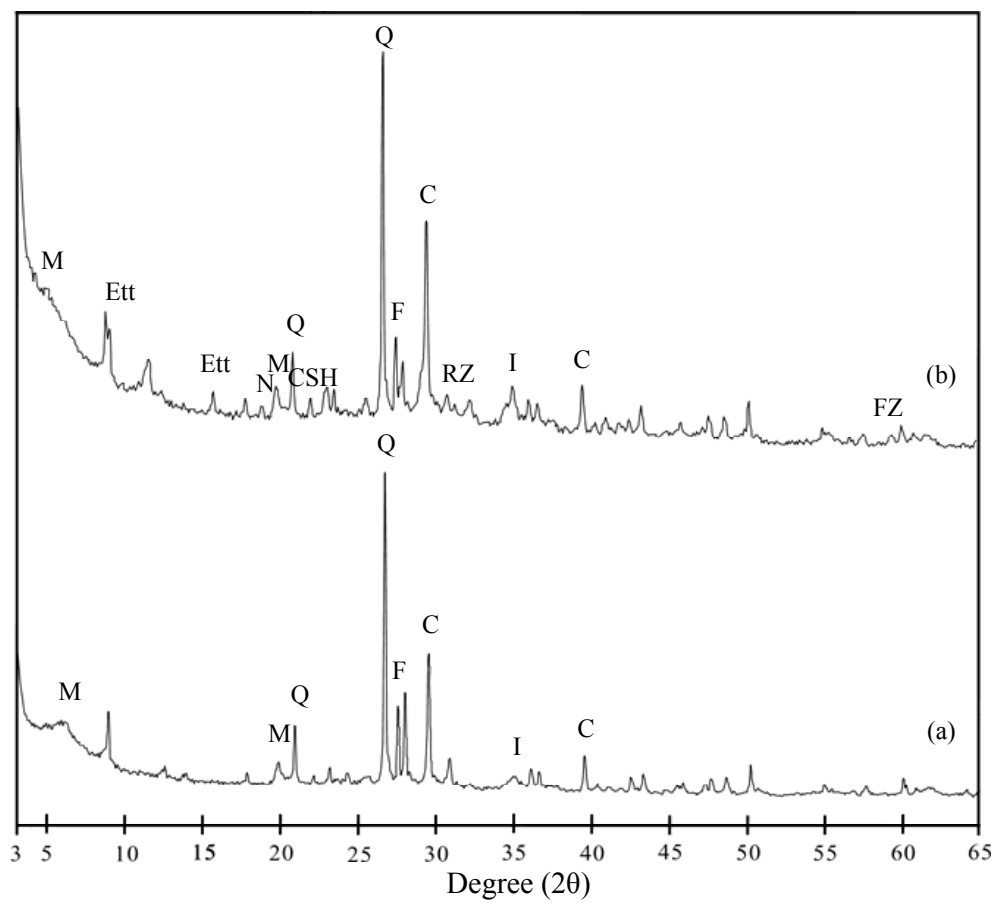

Fig. (5). XRD spectra for: (a) mud cake sample; (b) agglomerated cake sample. (Key: Q: Quartz; M: Montmorillonite; I: Illite; C: Calcite; F: Feldspar; RZ: Rod zeolite; FZ: Film zeolite; CSH: Calcium silicate hydrates; Ett: Ettringite; N: Natrolite.)

tween the cement paste and mud cake with MCM is modified. New ions such as $\mathrm{H}_{3} \mathrm{SiO}_{4}^{-}$and $\mathrm{AlO}_{2}^{-}$form during the process. The reaction equations are as follows:

$$
\begin{aligned}
& \mathrm{H}_{2} \mathrm{O}+\mathrm{SiO}_{2}+\mathrm{NaOH} \rightarrow \mathrm{NaH}_{3} \mathrm{SiO}_{4} \\
& \mathrm{NaH}_{3} \mathrm{SiO}_{4} \rightarrow \mathrm{Na}^{+}+\mathrm{H}_{3} \mathrm{SiO}_{4}^{-} \\
& \mathrm{Al}_{2} \mathrm{O}_{3}+2 \mathrm{NaOH} \rightarrow 2 \mathrm{NaAlO}_{2}+\mathrm{H}_{2} \mathrm{O} \\
& \mathrm{NaAlO}_{2} \rightarrow \mathrm{Na}^{+}+\mathrm{AlO}_{2}^{-}
\end{aligned}
$$

\subsection{Depolymerization}

The main components of mud cake with MCM are bentonite and substances with pozzolantic activity. The bentonite is mainly composed of aluminate and silicate minerals, whose properties is up to the type and content of montmorillonite $\left(\mathrm{CaMg}_{2} \mathrm{AlSi}_{4}(\mathrm{OH})_{2} \cdot \mathrm{H}_{2} \mathrm{O}\right)$ in it. The substances with pozzolantic activity are mainly composed of calcium-rich phase and silicon-rich phase.

The hydration ions from the cement slurry are mainly $\mathrm{Na}^{+}, \mathrm{Ca}^{2+}, \mathrm{OH}^{-}, \mathrm{SiO}_{4}{ }^{4-}, \mathrm{AlO}_{2}{ }^{-}$and $\mathrm{SO}_{4}{ }^{2-}$. $\mathrm{OH}^{-}$can cause the bond breaking of $\mathrm{Ca}-\mathrm{O}$ and $\mathrm{Mg}-\mathrm{O}$ in the substances with pozzolantic activity. It accelerates the replacement of $\mathrm{Ca}^{2+}$ and $\mathrm{Mg}^{2+}$ with $\mathrm{Na}^{+}$in FCCA. The reaction equations in the calcium-rich phase are as follows:

$$
\begin{aligned}
& \equiv \mathrm{Si}-\mathrm{O}-\mathrm{Ca}-\mathrm{O}-\mathrm{Si} \equiv+\mathrm{NaOH} \rightarrow 2(\equiv \mathrm{Si}-\mathrm{ONa})+\mathrm{Ca}(\mathrm{OH})_{2} \\
& \equiv \mathrm{Si}-\mathrm{O}-\mathrm{Mg}-\mathrm{O}-\mathrm{Si} \equiv+\mathrm{NaOH} \rightarrow 2(\equiv \mathrm{Si}-\mathrm{ONa})+\mathrm{Mg}(\mathrm{OH})_{2}
\end{aligned}
$$

The formation of $\mathrm{Ca}(\mathrm{OH})_{2}$ during this reaction is similar to portlandite (a hydration product of class $\mathrm{G}$ oilwell cement). Then silicate minerals would be decomposed gradually in alkaline solution. The reaction equations are as follows: 
$\equiv \mathrm{Si}-\mathrm{O}-\mathrm{Si} \equiv+\mathrm{H} \cdot \mathrm{OH} \rightarrow 2(\equiv \mathrm{Si}-\mathrm{OH})$

$\equiv \mathrm{Si}-\mathrm{OH}+\mathrm{NaOH} \rightarrow \equiv \mathrm{Si}-\mathrm{ONa}+\mathrm{H} \cdot \mathrm{OH}$

In addition, the basic structural units of montmorillonite are silicon-oxygen tetrahedron $\left(\left[\mathrm{SiO}_{4}\right]\right)$, silicon-oxygen tetrahedron $\left(\left[\mathrm{AlO}_{4}\right]\right)$ and alumina octahedral $\left(\left[\mathrm{AlO}_{6}\right]\right)$. Under the effect of the cement slurry filtrate, the montmorillonite reacts with $\mathrm{OH}^{-}$to form $\mathrm{H}_{3} \mathrm{SiO}_{4}{ }^{-}$and $\mathrm{H}_{3} \mathrm{AlO}_{4}{ }^{2-}$. The reaction equations are as follows:

$\mathrm{H}_{2} \mathrm{O}+\equiv \mathrm{Si}-\mathrm{O}-\mathrm{Si} \equiv+\mathrm{OH}^{-} \rightarrow \mathrm{H}_{3} \mathrm{SiO}_{4}^{-}$

$\mathrm{H}_{2} \mathrm{O}+=\mathrm{Al}-\mathrm{O}-\mathrm{Al}=+\mathrm{OH}^{-} \rightarrow \mathrm{H}_{3} \mathrm{AlO}_{4}{ }^{2-}$

The montmorillonite and substances with pozzolantic activity are depolymerized by $\mathrm{OH}^{-}$from the hydration filtrate of cement slurry. The ions $\left(\mathrm{OH}^{-}, \mathrm{Ca}^{2+}, \mathrm{K}^{+}, \mathrm{Mg}^{2+}, \mathrm{H}_{3} \mathrm{SiO}_{4}^{-}\right.$, $\mathrm{H}_{3} \mathrm{AlO}_{4}{ }^{2-}$, etc) could diffuse into the mud cake through the corrosion spots and cracks.

\subsection{Diagenesis}

FAAC could lead to the bond breaking of $\mathrm{Si}-\mathrm{O}$ and replacement of aluminum when it contacts mud cake with MCM. The formed soluble ions are mainly $\mathrm{Ca}^{2+}, \mathrm{Na}^{+}, \mathrm{OH}^{-}$, $\mathrm{SiO}_{4}{ }^{2-}, \mathrm{H}_{3} \mathrm{SiO}_{4}{ }^{-}, \mathrm{AlO}_{2}{ }^{-}$and $\mathrm{SO}_{4}{ }^{2-}$. The montmorillonite and substances with pozzolantic activity are depolymerized by $\mathrm{OH}^{-}$from the hydration filtrate of cement slurry. The formed soluble ions are mainly $\mathrm{Na}^{+}, \mathrm{Ca}^{2+}, \mathrm{OH}^{-}, \mathrm{SO}_{4}{ }^{2-}, \mathrm{H}_{3} \mathrm{SiO}_{4}{ }^{-}$and $\mathrm{H}_{3} \mathrm{AlO}_{4}{ }^{2-}$.

Under the conditions of supersaturated solution and certain temperature, the synergism of MCM with FAAC results in the diagenesis at CFI. As a result, a great amount of gel materials are formed, such as zeolite hydration products and calcium silicate hydrates (CSH). These gels fill in CFI gradually. Consequently, ISC among cement paste, agglomerated cake and formation at CFI is achieved. The reaction equations of diagenesis are as follows:

$\mathrm{OH}^{-}+\mathrm{SiO}_{4}^{4-}+\mathrm{Ca}^{2+}+\mathrm{H}_{2} \mathrm{O} \rightarrow \mathrm{Ca}_{4.5}\left[\mathrm{Si}_{6} \mathrm{O}_{15}(\mathrm{OH})_{3}\right] \cdot 2 \mathrm{H}_{2} \mathrm{O}$ (CSH)

$\mathrm{OH}^{-}+\mathrm{AlO}_{2}^{-}+\mathrm{SO}_{4}{ }^{2-}+\mathrm{Ca}^{2+}+\mathrm{H}_{2} \mathrm{O} \rightarrow$ $3 \mathrm{CaO} \cdot \mathrm{Al}_{2} \mathrm{O}_{3} \cdot 3 \mathrm{CaSO}_{4} \cdot 32 \mathrm{H}_{2} \mathrm{O}(\mathrm{Ett})$

$\mathrm{OH}^{-}+\mathrm{H}_{3} \mathrm{AlO}_{4}{ }^{2-}+\mathrm{H}_{3} \mathrm{SiO}_{4}^{-}+\mathrm{Ca}^{2+}+\mathrm{H}_{2} \mathrm{O} \rightarrow$ $\mathrm{CaAl}_{2} \mathrm{Si}_{7} \mathrm{O}_{18} \cdot 6 \mathrm{H}_{2} \mathrm{O}(\mathrm{FZ})$

$\mathrm{Na}^{+}+\mathrm{OH}^{-}+\mathrm{H}_{3} \mathrm{AlO}_{4}{ }^{2-}+\mathrm{H}_{3} \mathrm{SiO}_{4}^{-}+\mathrm{Ca}^{2+}+\mathrm{H}_{2} \mathrm{O} \rightarrow$ $\mathrm{NaCa}_{2} \mathrm{Al}_{5} \mathrm{Si}_{5} \mathrm{O}_{20} \cdot 6 \mathrm{H}_{2} \mathrm{O}(\mathrm{RZ})$

$\mathrm{Na}^{+}+\mathrm{OH}^{-}+\mathrm{H}_{3} \mathrm{AlO}_{4}{ }^{2-}+\mathrm{H}_{3} \mathrm{SiO}_{4}{ }^{-}+\mathrm{H}_{2} \mathrm{O} \rightarrow$ $\mathrm{Na}_{2} \mathrm{Al}_{2} \mathrm{Si}_{3} \mathrm{O}_{10} \cdot 2 \mathrm{H}_{2} \mathrm{O}(\mathrm{N})$

\section{CONCLUSIONS}

The mud cake with MCM can be modified by FAAC. A large amount of corrosion spots and cracks could be observed on the surface of mud cake. These corrosion spots and cracks provide channels for the diffusion of ions from the cement slurry, and accelerated the formation of gels. The concentrations of alkali metal cations $\left(\mathrm{Na}^{+}, \mathrm{Ca}^{2+}, \mathrm{K}^{+}, \mathrm{Mg}^{2+}\right.$, $\left.\mathrm{Fe}^{2+}, \mathrm{Zn}^{2+}, \mathrm{Al}^{3+}\right)$ in inner layer of agglomerated cake are higher than those in the outer layer. The concentration dif- ference provides power for the diffusion of ions into mud cake.

The mud cake with MCM contained a mass of bentonite and substances with pozzolantic activity. They are depolymerized by $\mathrm{OH}^{-}$from the hydration filtrate of cement slurry, and form the soluble ions $\left(\mathrm{Na}^{+}, \mathrm{Ca}^{2+}, \mathrm{OH}^{-}, \mathrm{SO}_{4}{ }^{2-}, \mathrm{H}_{3} \mathrm{SiO}_{4}{ }^{-}\right.$ and $\left.\mathrm{H}_{3} \mathrm{AlO}_{4}{ }^{2-}\right)$. These soluble ions react with the ions $\left(\mathrm{Na}^{+}\right.$, $\mathrm{Ca}^{2+}, \mathrm{OH}^{-}, \mathrm{SiO}_{4}{ }^{4-}, \mathrm{AlO}_{2}{ }^{-}, \mathrm{SO}_{4}{ }^{2-}$ and $\mathrm{H}_{3} \mathrm{SiO}_{4}{ }^{-}$) from $\mathrm{FAAC}$ and cement slurry filtrate, and forms gel materials $(\mathrm{CSH}$, ettringite, film zeolite, rod zeolite and natrolite). These gels inserted among cement paste, agglomerated cake and formation, and ISC at CFI is achieved by these gels. Finally, the isolation quality of CFI is improved by the MTA method.

\section{CONFLICT OF INTEREST}

The authors confirm that this article content has no conflicts of interest.

\section{ACKNOWLEDGEMENTS}

This study was financially supported by the National Natural Science Foundation of China (Nos. 51174180 and 40972103).

\section{REFERENCES}

[1] J. Gu, P. Zhong, C. Shao, S.H. Bai, H. Zhang, and K. Li, "Effect of interface defects on shear strength and fluid channeling at cementinterlayer interface". J. Petrol. Sci. Eng., vol. 100, pp. 117-122, 2012.

[2] H.K.J. Ladva, B. Craster, T.G.J. Jones, G. Goldsmith, and D. Scott, "The cement-to-formation interface in zonal isolation". J. Petrol.Technol., vol. 57, pp. 41-42, 2005.

[3] K.M. Cowan, A.H. Hale, and J.J. Nahm, "Conversion of drilling fluids to cements with blast furnace slag: Performance properties and applications for well cementing". In: SPE Annual Technical Conference and Exhibition, 4-7 October 1992, Washington, DC, USA, 1992.

[4] O.G. Benge, and W.W. Webster, "Evaluation of blast furnace slag slurries for oilfield application". In: Proceedings of the Drilling Conference. 15-18 February 1994, Dallas, TX, USA, 1994.

[5] Z. Xiao, M. Wu, and M. Xu, "The induced mechanism of crystal during hydratie of blast-furnace slag". Acta Petrol. Sin., vol.19, pp. 117-121, 1998

[6] Z. Peng, Y. He, and C. Liu, "Basic causes analysis of cracking of MTC solidified body with cinder”. Nat. Gas. Ind., vol.25, pp. 7274, 2005.

[7] J. Gu, "Problem of the cement-formation interface and scientific conception of mud cake to agglomerated cake". J. Oil Gas. Technol., vol. 19, pp. 117-121, 2009.

[8] J. Gu, and W. Qin, "Experimental study on integrated solidification and cementation of cement-formation interface based on Mud Cake to Agglomerated Cake (MTA) method". Petrol. Explor. Dev., vol. 37, pp. 226-231, 2010.

[9] J. Gu, W. Yang, Y. Zhang, Y. Gao, X. Liu, and T. Li, “Association between tuff di agenesis and mud cake to agglomerated cake (MTA) at cement-formati on interface". J. China Univ. Petrol. (Nat. Sci. Edi.), vol. 35, pp. 64-68, 2011.

[10] J. Gu, P. Zhong, W. Qin, H. Liu, L. Dong, and Y. Yang, "Kinetic Models of Integrated Solidification and Cementation of Cementformation Interface with New Method". Open Chem. Eng. J., vol. 7, pp. 9-17, 2013.

[11] J. Gu, Y. Yang, L. Dong, P. Zhong, and H. Zhang, "Technical principle of integrated solidification and cementation at cementformation interface with Mud Cake to Agglomerated Cake (MTA) 
method and its oilfield application". Adv. Mater. Res., vol. 236238, pp. 2864-2867, 2011

[12] J. Gu, X. Li, H. Liu, Y. Zhang, and Y. Gao, "Laboratory evaluation and application of new materials based on Mud Cake to Agglomer- ated Cake (MTA) method". Adv. Mater. Res., vol. 148-149, pp. 449-452, 2011.

[13] J. Gu, B. Wang, and B. Yang, "The influences of interface missing and formation property on shearing strength at cement-formation interface". Petrol. Sci. Technol., vol. 29, pp. 633-639, 2011.

Received: April 23, 2008

Revised: May 26, 2008

Accepted: June 2, 2008

(C) Gu et al.; Licensee Bentham Open.

This is an open access article distributed under the terms of the Creative Commons Attribution License (http://creativecommons.org/licenses/by/2.5/), which permits unrestrictive use, distribution, and reproduction in any medium, provided the original work is properly cited. 